Article

\title{
Approaching Monetary Integration in the Context of the Imperative to Ensure the Sustainable Growth in the EU
}

\author{
Ionel Bostan ${ }^{1, * \mathbb{D}}$, Otilia-Roxana Oprea ${ }^{2}$ and Ovidiu Stoica ${ }^{2} \mathbb{D}$ \\ 1 Faculty of Law and Administrative Sciences, Ştefan cel Mare University, Universitatii 13, \\ 720229 Suceava, Romania \\ 2 Faculty of Economics and Business Administration, Alexandru Ioan Cuza University, 22 Carol I, \\ 700505 Iasi, Romania; otiliaoprea40@gmail.com (O.-R.O.); ostoica@uaic.ro (O.S.) \\ * Correspondence: ionel.bostan@fdsa.usv.ro; Tel.: +40-230-216-147
}

Received: 12 August 2020; Accepted: 26 August 2020; Published: 30 August 2020

\begin{abstract}
Sustainable economic growth is an essential objective at the European Union level. The purpose of this paper is to investigate the impact of monetary integration on economic growth, assuming that the introduction of the euro significantly stimulated the process of European financial integration. We used a fixed-effects methodology for panel data for the EU 28 countries for the period 2004-2018. We find that the main factors through which monetary integration contributessignificantly and positively to economic growth areeconomic growth Single Euro Payments Area (SEPA)cards, trade, monetary freedom, convergence of interest rates, convergence of exchange rates and cross-border holdings of short-term debt, with significant differences between Eurozone and non-euro countries, which confirms the hypothesis that the introduction of the euro had a significant impact on economic and financial integration.
\end{abstract}

Keywords: banking and monetary integration; European Union; SEPA instruments; sustainable economic convergence

\section{Introduction}

An important step towards tightening up the European financial integration process is the formation of the Economic and Monetary Union (EMU), known as the euro area. In 1999, when most EU countries fixed their nominal exchange rates in one currency, the euro area was formed, creating the largest single monetary area. Since then, the European Central Bank has implemented a common monetary policy based on the euro, and member countries have renounced their own monetary policies in favor of alignment with this common policy. Moreover, the euro area Member States should coordinate their fiscal activity policies under the Stability and Growth Pact, which imposes certain limits on national debt and government borrowing. An effective vision should face the long-term challenges of the EMU, as the euro area is diverse, and thus policymaking at the national level in line with the single monetary policy may be the most effective method for economic decisions, maintaining an adequate level of competitiveness, convergence and coordination to ensure sustainable economic growth. Monetary integration is another branch of financial integration thatis related to monetary policy and introducing the euro. It had an increased effect on FDI (foreign direct investments) inflows and trade [1]. The monetary integration concept can be defined as waiving exchange rate policies and the use of monetary policy for achieving only national goals; moreover, long-run monetary integration means the adoption of a European single currency [2].

The theoretical framework employed is the monetarists' debate, because we think that monetary integration will facilitate economic integration, and monetary integration can be considered an engine 
of financial integration, because, based on own studies, we have noticed that it has a positive and significant impact on the other two market segments investigated - the banking market and the capital market.The main purpose of this chapter is to investigate the impact of monetary integration on sustainable economic growth in EU countries, assuming that the introduction of the euro has had a major influence on the process of financial integration. Additionally, as a secondary goal, we wanted to find out the main factors through which the development of the money market influences economic growth, by selecting the most relevant indicators proposed by the literature and building an econometric model.The motivation of this research is based on a current problem, related to non-Eurozone EU member countries striving to join the Euro who, in their efforts, need to re-evaluate its merits and demerits. Additionally, we can say that financial markets are considered integrated when the single price law works, i.e., when securities with identical cash flows order the same price.

Research questions:

1. What are the factors through which European monetary integration influences economic growth?

2. Which of these factors have a greater impact on economic growth?

3. What is the (positive or negative) impact of European bank integration on growth?

The originality of this paper is the use of a significant number of variables that measure monetary integration, thathave been proposed by other authors to quantify monetary integration but have not been used in models relating to the linkage between European monetary integration and economic growth. Secondly, we used a more recent period for analyzing our data (2004-2018), with most of the previous studies having data up to 2014. Thirdly, the research undertaken contributes to the literature, analyzing the impact of monetary integration on the growth of the economy, and finding the most important factors to highlight this impact, as they are important for monetary authorities to adopt policies to support the process integration in order to achieve stability and growth in good conditions.

\section{Theoretical Background}

\subsection{Monetary Integration and Monetary Policy}

Monetary policy can be defined as comprising a series of measures thatlead to an influence on the volume, the cost and the availability of credit and money so as to achievecertain set objectives [3]. In analyzing business cycle asymmetries in open economies, monetary unions should be taken into account, including the financial frictions and their interactions with nominal rigidities [4]. Additionally, in terms of the banking sector, the impact of monetary policy on the bank's appetite and perception of risk may induce banks to take excessive risks, especially when an expansionary monetary policy is implemented [5].

In the European space, issues such as those addressed by us have been the subject of research concerns of reputable specialists conducted several years ago [6-8], but we point out here a more recent issue, in the same direction, taking into account works recently published [9-12]. From another perspective, only in an additional way, so without having a high relevance in the EU/Eurozone context, we refer briefly to other spaces/epochs; some of the authors who have studied this topic have analyzed the effects of monetary policy in different countries.

To estimate the economic costs of a monetary union, we must compare the value of exchange rate policy solution against asymmetric real shocks, because the exchange rate policies help this against this shocks, and also, the flexibility of wages and prices will be higher in a monetary union (Table 1). 
Table 1. Benefits and costs of a Currency Union [13].

\begin{tabular}{cc}
\hline Benefits (According to the Openness of the Economy) & Costs \\
\hline The reduction of transaction costs & $\begin{array}{c}\text { Inflation and seigniorage tax aren't available for the } \\
\text { national governments }\end{array}$ \\
\hline The markets are more transparent (indirect influence) & $\begin{array}{c}\text { The abandonment of the exchange rate policy needed } \\
\text { for balance the intra-union asymmetrical shocks }\end{array}$ \\
\hline The reduction of price discrimination & $\begin{array}{c}\text { According to the wage and price rigidity, the } \\
\text { countries are "different" }\end{array}$ \\
\hline The decrese of monetary investment risks \\
Growth effects
\end{tabular}

\subsection{Cross-Border Payments}

Payment systems are important for integration because the integration of the money markets and wholesale banking activities has been fostered by the large value of the payment systems (mostly used for interbank payment transactions) $[13,14]$.

Cross-borders payments referring to transactions involving companies, individuals, settlement institutions operating in at least two different countries, which offers settlement and clearing services for its participants. The countries involved do not need to share a border. For example, a payment from the UK to Spain will be regarded as a cross-border payment, even though they are not neighboring countries. Additionally, when the two countries involved in the transaction use different currencies, the parties need to carry out a foreign currency exchange to complete the payment.

TARGET was the first payment system which was based on the principle of minimum harmonization, linking the ECB (European Central Bank) payment mechanism and the national settlement systems of the $15 \mathrm{EU}$ members into a single platform. Subsequently, this system was replaced with TARGET2, which was expected to offer a single pricing structure, a harmonized set of cash settlement services and also a single technical communication interface for multi-country users $[13,14]$.

SEPA (Single Euro Payments Area) deals with harmonization with the way cashless euro payments are made across Europe and establishes a single set of tools and standards that make cross-border payments in euro as easy as national payments. Regarding the rules on charges for cross-border payments in euro, the principle of equal charges applies for: credit transfers, direct debits, withdrawals at cash dispensers (ATMs), payments by debit and credit cards, and money remittance. The most popular and most used payment instruments are credit transfers, direct debits, and credit cards [15-19]. In Figure 1, we can see that the growth in electronic payment instruments registered an upward trend over time. This means that non-cash payments could achieve sustained growth throughout Europe if payment service providers, customers and merchants would fully engage in their use and development.

With the help of the SEPA credit transfer (SCT) indicator, the Eurosystemoversees the migration from domestic credit transfers to SCT of the Eurozone. As we can see in Figure 2, the use of SCT recording a steady ascendant evolution, accounting for $9.3 \%$ of the total credit transfer volume in August 2010. Moreover, the situation in each country with regard to the market share of national legacy products and SCT is seen in a concise image with the help of the national SCT indicators. 


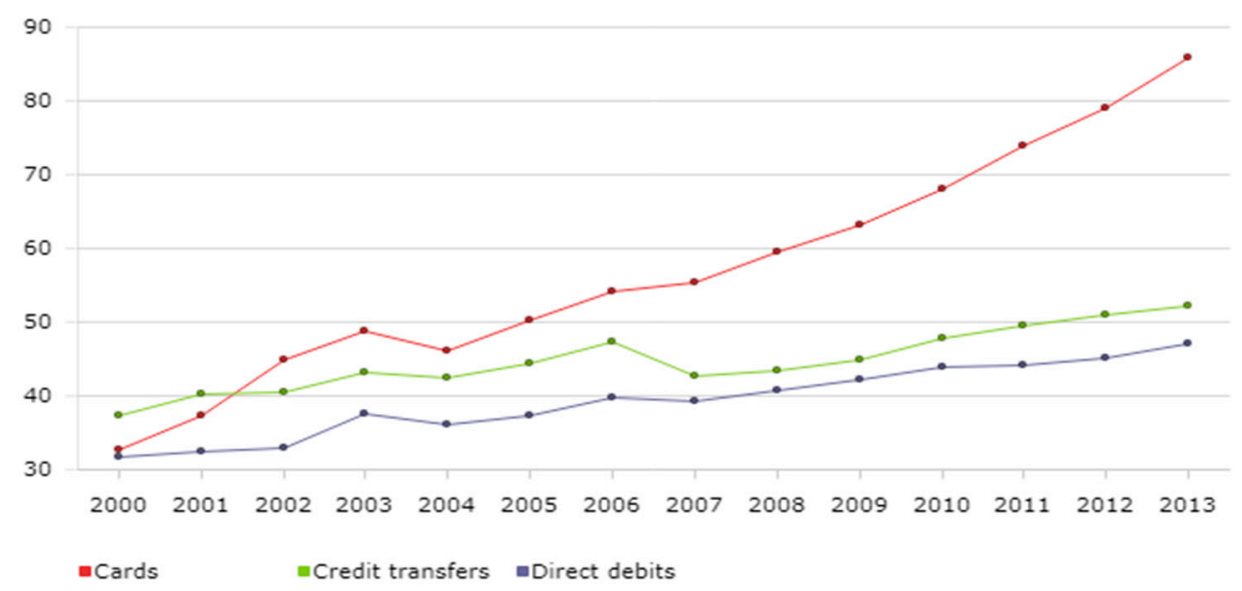

Figure 1. Growth in electronic payment instruments per capita per year in the EU.Source: European Central Bank (2014), Understanding payments-Types of payments.

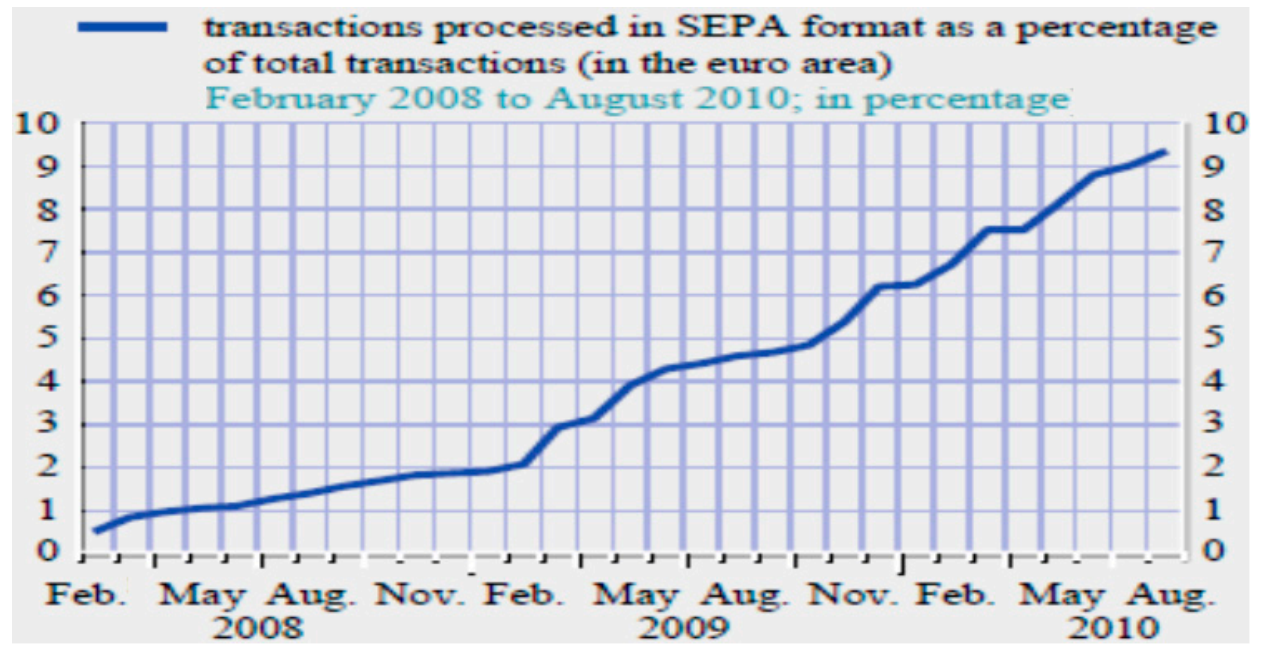

Figure 2. Single Euro Payments Area(SEPA) credit transfers as a percentage of all credit transfer transactions in the Eurozone.Source: European Central Bank (2010). Single Euro Payments Area.

In the figure below (Figure 3), we can see the share of SCT in the inter-bank domain as a percentage of the total volume of credit transfers. The use of the new SEPA product is higher with the higher value of SCT. A value of $100 \%$ would mean that that only SEPA products are used and have fully substituted other instruments. Additionally, the bars show the total number of SCT transactions analyzed by the infrastructures from the Eurozone.

STEP (Short-Term European Paper) was an initiative of the Financial Market Association which aimed to identify a set of common market practices to foster market integration and financial integration for short-term securities $[13,14]$.

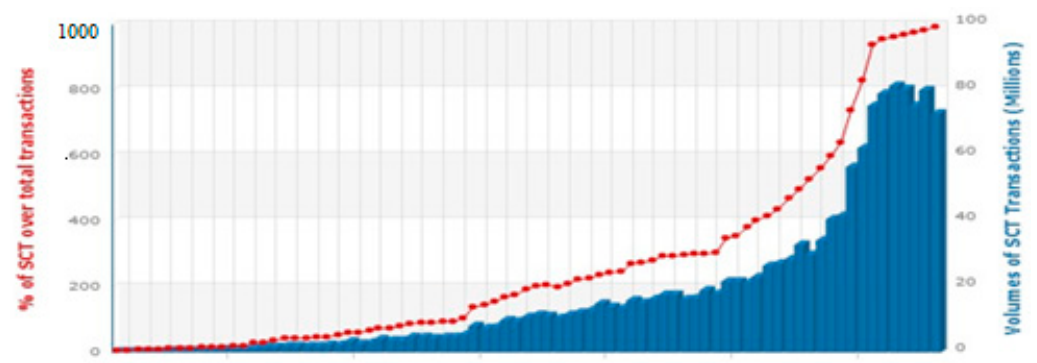

Figure 3. Transactions analyzed in SEPA format (Eurozone).Source: European Central Bank, Payment integration-SEPA, Migration indicators, Migration of credit transfers. 


\section{Data and Methodology}

Studies conducted so far on this topic have used various indicators to measure monetary integration, such as: inflation, exchange rates, money supply, exports, imports, interest rates, capital-labor, currency supply, interbank rates, foreign reserve, unemployment rate, trade openness, international investment position, exchange rates volatility, foreign direct investments, labor mobility, wage and price flexibility. In this article, we used some indicators that have been used in previous research, such as consumer price index, long-term interest rates, multifactor productivity, GDP, exchange rates, money supply, trade, unemployment rates, monetary freedom, but also some indicators which have not been used in the revised studies on this topic, such as SEPA credit transfers, SEPA direct debit, SEPA cards, and cross-border holdings of short-term debt.

Interest rates are single price indicators that were used in various studies on this subject [4,20-25]. They are important because whentheyare high, fewer people and businesses can afford to borrow, which leads to reductions inthe amount of credit available to fund purchases, slowing consumer demand, while lowinterestrates makebusiness loansmore affordable, whichencourages business expansion and new jobs. We calculated the convergence of interest rates because according to the Maastricht Treaty, a high rate of convergence of interest rates can positively influence the monetary integration [26,27] and, as opposed to the revised studies, we used the harmonized long-term interest rates for convergence purpose (CONINT).

The consumer price index is an indicator of price stability which was used in some studies, which is important because the changes in CPI ( consumer price index) are often used to evaluate price changes associated with the cost of living, and also it is used to identify periods of inflation or deflation. It can be used as an index of the erosion of living standards, and a high rate of inflation can discourage the monetary policy and affect economic growth. We used the convergence of this indicator as a measure of price stability, the primary objective of EMU and conducive to growth (CONCPI).

Exchange rates are indicators of competitiveness thatwere used in other studies $[20-24,28]$ and can make a connection between the currencies of two countries. The reduction of volatility or the better management of the trade relations can be achieved by fixing the exchange rate, and also the exchange rate can have a negative influence on economic growth in the absence of stability. Moreover, an effective mechanism to enhance the integration of product markets between different countries can be considered the alignment of the exchange rate and interest rate policies [24]. According to Walti [26], the convergence of exchange rate has only been used as a measure of exchange rate stability, necessary for monetary integration (CONEXR). Money supply (MS) is an indicator which was used in other research $[29,30]$ and it isessential because it reflects the different types of money existing in an economy, which are analyzed by the economists in order to develop monetary policies through increasing or decreasing the amount of money flowing in an economy and controlling the interest rates, money supply having a strongly positive influence on output. Additionally, the possible changes in the money supply can affect the financing of government budgets, which can limit the economic and monetary policies, and adjusting the money supply is considered a common tool for managing the economic activity, so it is an important factor for monetary integration.

Trade is an indicator thatwas used by other authors $[21,25,31]$ to measure the openness of the economy, because, in the areas which have a high degree of economic openness is needed a fixed exchange rate to keep the value of the liquidity of an individual currency. Moreover, this indicator will show us the bilateral trade status, and also the degree of openness of an economy is essential to foster a government's freedom to supervise the susceptibility of a country to international economic cycles and the economic policies of its choice, one of EMUs objectives is the reduction of transaction costs of cross-border trade, the transaction cost savings will be significant [25] to eliminate the barriers between countries in line with the movement of goods, labor, services and capital, so the increase of this indicator can positively influence monetary integration. 
Additionally, according to the literature [32], we used as control variables some determinants of economic growth: public spending (PSP) employment (unemployment rate-UNEM), the budget deficit (BDEF), gross national savings (GRS). For gross national savings, a higher value can positively influence the economic growth, because it indicates the financial state and growth of the country, as household saving is the principal source of government borrowing to fund public services, while for the others indicators, a higher value can have a negative influence on economic growth. For example, the unemployment rate is an indicator which was used in various studies [33] and which decreases or increases according to the changes in economic conditions (it can be expected to increase when the economy is in poor shape and jobs are rarefied, and to decrease when the jobs are plenty and the economy is evolving at a healthy rate).

Monetary freedom (MONFR) is an indicator proposed by the Heritage Foundation, whichwas used by Cham [1], and it can be important for the quantification of monetary integration, because it combines an assessment of price controls with a measure of price stability, both of them being factors which havea negative impact on the market activity. It is based on the price controls and the weighted average inflation rate. The ideal state for the free market is represented by the price stability without the influence of macroeconomic intervention.

Cross-border holdings of short-term debt securities (CRHO) is an indicator which was not used in the revised studies on this topic, but was proposed by European Central Bank [16-18] as a quantity-based indicator of money markets, although the cross-border activity in the euro area short-term debt are limited in comparison with equity and bond markets, and the price-based indicators are more relevant in this case. It is considered an important indicator whose growth is in line with good market integration, and which recorded an upward trend over the period 2000-2007, followed by a downturn during the financial crisis.Cross-border activity also plays an important role in highlighting the relationship between money market integration and economic growth, with statistics suggesting an increase after the introduction of the euro.

SEPA credit transfers (SCT), SEPA direct debit (SDD) and SEPA cards (SC) are indicators of the cross-border payments, which has not been used in the revised studies on this topic, but, as we argued in Section 2.1 they are important factors of money markets.In addition to convergence indicators, SEPA instruments also play a key role in facilitating monetary integration, as the operation of this system can bring many benefits to economic growth and stability, such as increasing competition in the banking industry by removing barriers previously protected by national markets, guaranteeing cost savings in processing payments and thus the emergence of new business opportunities, stimulating innovation, improving trading conditions for bank customers.Countries can only enjoy these benefits if all euro payments (for Eurozone countries) are treated as domestic payments and when the distinction between national and cross-border payments disappears. The institutions that could benefit most from the SEPA project are those that carry out new technological developments, create new companies or businesses and provide innovative services.

In terms of economic growth, we know that the most common way tomeasurethe economyis the real gross domestic product, or real GDP $[1,4,20-23,30,31]$. This is used to account for the relative size of a country, and also it is based on the assumption that the countries with a higher GDP will have relatively higher internal bank markets, the percentage of the foreign bank assets in the country being lower than in the case of the small states. Another indicator less used in the studies $[21,23,31,34]$ is labor productivity, because the increases of this indicator (the ratio of the value of output to labor input) have historically been the most important source of real per capita economic growth. We will use the indicator total factor productivity (TFP).

The data are focused on the period 2004-2018, with an annual frequency and unbalanced (because some indicators have not reported the values for all these years), which wereobtained by Eurostat, Federal Reserve Economic Data, ECB, OECD, Heritage Foundation, and are used in the EU 28 countries simply. 
Regarding the methodology, the used methods in the research studies that analyze the relationship between monetary integration and economic growth are regressions, VAR, VECM, GMM, Differences in Differences, cointegration analysis, GARCH, ARDL.Research that used regressions $[1,5,14,21,34]$ found that monetary integration is an important factor of economic growth. For example, Gul et al. [14] said that interest rates (when they are high) and the exchange rate have a negative and significant impact on output, but money supply has a positive and significant impact. Barrellet al. [21] found that the introduction of the euro has had a positive impact on growth and may increase the output by diminishing the output volatility.Studies that used VECM methodology [22] said that monetary policies should be used to create a favorable investment climates with the aim to foster economic growth.Another methodology used by some authors from the revised studies is Differences in Differences [14,24,34], pointing out that the alignment of interest rate and exchange rate policies is effective for strengthening the integration of product markets.

In this study, we used the regression analysis with country FE and year FE, because it is the most appropriate for our panel data according to the statistical tests. The dependent variable was economic growth, expressed by GDP and total factor productivity, and the independent variables were money supply, trade, monetary freedom, unemployment rates, budget deficit, public spending, gross savings, the convergence of inflation, exchange rates and interest rates, SEPA credit transfers, direct debits and cards and cross-border holdings of short-term debt securities.

Our equation containing fixed effects took the following form:

$$
\begin{gathered}
\ln _{G D P_{i t}=} \beta_{0}+\beta_{1} * \mathrm{CONCPI}+\beta_{2} * \mathrm{CONEXR}+\beta_{3} * \mathrm{MS}+\beta_{4} * \mathrm{TRADE}+\beta_{5} * \mathrm{MONFR}+\beta_{6} * \\
\operatorname{lnSCT}+\beta_{7} * \operatorname{lnSDD}+\beta_{8} * \operatorname{lnSC}+\beta_{9} * \mathrm{CONINT}+\beta_{10} * \operatorname{lnCRHO}+\beta_{11} \\
* \mathrm{PSP}+\beta_{12} * \mathrm{GRS}+\beta_{13} * \mathrm{BDEF}+\beta_{14} * \mathrm{UNEM}+\alpha_{i}+\varepsilon_{i t}
\end{gathered}
$$

where $i$-country, $t$-time, $\alpha_{i}(i=1, \ldots, n)$ is the unknown intercept for each country $(n$ country-specific intercepts) and $\varepsilon_{i t}$ error term. The equation looks the same when we replace GDP with total factor productivity:

$$
\begin{gathered}
\mathrm{TFP}=\beta_{0}+\beta_{1} * \mathrm{CONCPI}+\beta_{2} * \mathrm{CONEXR}+\beta_{3} * \mathrm{MS}+\beta_{4} * \mathrm{TRADE}+\beta_{5} * \mathrm{MONFR}+\beta_{6} * \\
\operatorname{lnSCT}+\beta_{7} * \operatorname{lnSDD}+\beta_{8} * \ln \mathrm{CC}+\beta_{9} * \mathrm{CONINT}+\beta_{10} * \operatorname{lnCRHO}+\beta_{11} * \mathrm{PSP}+\beta_{12} * \mathrm{GRS}+\beta_{13} \\
* \mathrm{BDEF}+\beta_{14} * \mathrm{UNEM}+\alpha_{i}+\varepsilon_{i t}
\end{gathered}
$$

In order to analyze the monetary integration characteristics' influence on economic growth, we conducted two key hypotheses:

Hypothesis 1 (H1). Monetary integration has a positive impact on economic growth.

Hypothesis 2 (H2). Monetary integration has a greater impact on economic growth in the euro area.

Because the data are not normally distributed, according to the Shapiro-Wilk test and Shewkness Kurtosis test, we decided to clean the outliers by winsorization (keeping data between the percentile 1 and percentile 99). The descriptive statistics after data cleaning is displayed in the table below (Table 2): 
Table 2. Descriptive statistics.

\begin{tabular}{cccccc}
\hline Variables & Obs. & Average & Std. Dev. & Min & Max \\
\hline TFP & 392 & 1.08 & 0.50 & 0.2 & 4.85 \\
\hline MS & 391 & 4.23 & 0.63 & 2.21 & 5.98 \\
\hline TRADE & 392 & 4.66 & 0.46 & 3.86 & 5.94 \\
\hline MONFR & 392 & 81.03 & 4.17 & 67 & 90.1 \\
\hline UNEM & 392 & 8.94 & 4.22 & 3.7 & 24.9 \\
\hline BDEF & 392 & -2.67 & 3.35 & -13.8 & 5 \\
\hline PSP & 392 & 44.60 & 7.17 & 17.07 & 58.1 \\
\hline GRS & 391 & 21.75 & 5.70 & 7.98 & 36.73 \\
\hline CONCPI & 392 & 0.74 & 0.80 & 0.01 & 4.68 \\
\hline CONEXR & 392 & 10.98 & 25.51 & 1.45 & 157.03 \\
\hline CONINT & 392 & 0.89 & 0.88 & 0.02 & 5.40 \\
\hline GDP & 392 & 9.89 & 0.68 & 8.16 & 11.39 \\
\hline SCT & 383 & 20.35 & 2.99 & 10.89 & 27.85 \\
\hline SDD & 383 & 16.46 & 3.14 & 7.52 & 23.01 \\
\hline SC & 383 & 16.30 & 2.87 & 8.96 & 21.70 \\
\hline CRHO & 385 & 9.46 & 2.34 & 3.33 & 13.24 \\
\hline
\end{tabular}

\section{Results}

We estimated several models with the variables consideredinthe methodology section to see if the results are similar. Additionally, we applied some tests for panel data models (heteroskedasticity, individual and time effects, serial correlation and unit root tests) tovalidate our models. In order to control autocorrelation, heteroskedasticity and serial correlation, we used s robust covariance matrix - the Driscoll-Kraay model. Multicollinearity could be a problem in regression analysis if it is present, therefore we computed the VIF (Variance inflation factor) test, where all of the values are below 3 , so we can say that there are no multicollinearity problems for our models.We conducted the Hausman test to select between random and fixed effects models, and the probability is $0.00<0.05$ for all the models, so the fixed-effects models are more appropriate. Further tests (Wald test and Wooldridge's first-difference test) for serial correlation in panels suggest that "two-ways" models are the most appropriate ones (the time-fixed effects test suggests that time-fixed effects are needed). Additionally, tocontrol the reverse causality problem, we estimated some one-period lagged models (models Year FE (2) are estimated with lags). The results of the mentioned tests will be provided by the authors on demand.

Model 1, (Table 3) which was estimated for the entire database, shows us that the variables which have a positive and significant influence in almost all estimates are SEPA cards (SC), money supply (MS), trade (TRADE), monetary freedom (MONFR), convergence of interest rates (INT), gross savings (GRS), and cross-border holdings of short-term debt (CRHO), and the variables which have a significant but negative influence are the unemployment rates (UNEM) on both GDP and total factor productivity.

Among them, convergence-based indicators, as factors for the expression of the law of the single price, occupy a key place, due to the fact that countries' participation in the single monetary policy requires the meeting of the convergence criteria and acts as a disciplinary instrument in this regard. Although the indicators we use to measure convergence are based on the criteria of nominal convergence, nominal and real convergence are closely linked, as nominal convergence facilitates real convergence by ensuring stable macroeconomic conditions. 
Table 3. The impact of monetary integration on economic growth: Model 1-Initial database.

\begin{tabular}{|c|c|c|c|c|c|c|c|c|}
\hline \multirow{3}{*}{$\begin{array}{l}\text { Independent } \\
\text { Variables }\end{array}$} & \multicolumn{4}{|c|}{ Dependent Variable-GDP } & \multicolumn{4}{|c|}{ Dependent Variable-TFP } \\
\hline & \multirow{2}{*}{$\begin{array}{c}\text { OLS with } \\
\text { Years Dummy }\end{array}$} & \multicolumn{3}{|c|}{ Fixed Effects } & \multirow{2}{*}{$\begin{array}{c}\text { OLS with } \\
\text { Years Dummy }\end{array}$} & \multicolumn{3}{|c|}{ Fixed Effects } \\
\hline & & Country & E; Year FE; & lear FE (2) & & \multicolumn{3}{|c|}{ Country FE; Year FE; Year FE (2) } \\
\hline CONCPI & $\begin{array}{c}0.07^{* *} \\
(0.02)\end{array}$ & $\begin{array}{c}0.035^{* * *} \\
(0.007)\end{array}$ & $\begin{array}{l}0.01 * * \\
(0.006)\end{array}$ & $\begin{array}{l}0.02 * * * \\
(0.006)\end{array}$ & $\begin{array}{c}0.02 \\
(0.03)\end{array}$ & $\begin{array}{l}0.04 * \\
(0.04)\end{array}$ & $\begin{array}{c}0.04 \\
(0.04)\end{array}$ & $\begin{array}{l}0.02 * \\
(0.04)\end{array}$ \\
\hline CONEXR & $\begin{array}{c}0.005^{* * *} \\
(0.001)\end{array}$ & $\begin{array}{l}0.0001 \\
(0.002)\end{array}$ & $\begin{array}{c}0.006^{* * *} \\
(0.001)\end{array}$ & $\begin{array}{l}0.003 * \\
(0.001)\end{array}$ & $\begin{array}{l}0.001 \text { * } \\
(0.001)\end{array}$ & $\begin{array}{l}0.004 \\
(0.01)\end{array}$ & $\begin{array}{l}0.002 * \\
(0.01)\end{array}$ & $\begin{array}{c}0.001^{* * *} \\
(0.01)\end{array}$ \\
\hline SCT & $\begin{array}{l}0.05^{* * *} \\
(0.009)\end{array}$ & $\begin{array}{l}0.009 * \\
(0.005)\end{array}$ & $\begin{array}{c}0.003 \\
(0.003)\end{array}$ & $\begin{array}{c}0.001 \\
(0.003)\end{array}$ & $\begin{array}{l}0.005 \\
(0.01)\end{array}$ & $\begin{array}{c}0.04 \\
(0.02)\end{array}$ & $\begin{array}{l}0.04 * \\
(0.02)\end{array}$ & $\begin{array}{c}0.04 \\
(0.02)\end{array}$ \\
\hline SDD & $\begin{array}{l}0.05^{* * *} \\
(0.009)\end{array}$ & $\begin{array}{l}-0.002 \\
(0.002)\end{array}$ & $\begin{array}{l}0.0006 \\
(0.002)\end{array}$ & $\begin{array}{c}0.001 \\
(0.002)\end{array}$ & $\begin{array}{l}0.009 \\
(0.01)\end{array}$ & $\begin{array}{l}0.03^{*} \\
(0.01)\end{array}$ & $\begin{array}{l}0.03^{*} \\
(0.01)\end{array}$ & $\begin{array}{c}0.04 \\
(0.02)\end{array}$ \\
\hline SC & $\begin{array}{l}0.01 \text { ** } \\
(0.009)\end{array}$ & $\begin{array}{l}0.07^{* * *} \\
(0.008)\end{array}$ & $\begin{array}{l}0.02 * * * \\
(0.007)\end{array}$ & $\begin{array}{l}0.01 * * * \\
(0.006)\end{array}$ & $\begin{array}{l}0.001 \\
(0.01)\end{array}$ & $\begin{array}{l}0.06^{*} \\
(0.04)\end{array}$ & $\begin{array}{c}0.04 \\
(0.04)\end{array}$ & $\begin{array}{l}0.05^{*} \\
(0.05)\end{array}$ \\
\hline MS & $\begin{array}{c}0.15^{* * *} \\
(0.03)\end{array}$ & $\begin{array}{l}0.01 * \\
(0.01)\end{array}$ & $\begin{array}{l}0.02 * * \\
(0.01)\end{array}$ & $\begin{array}{l}0.02 * * \\
(0.01)\end{array}$ & $\begin{array}{c}0.05 \\
(0.04)\end{array}$ & $\begin{array}{c}0.02 * * * \\
(0.06)\end{array}$ & $\begin{array}{c}0.05 \\
(0.06)\end{array}$ & $\begin{array}{l}0.16^{*} \\
(0.09)\end{array}$ \\
\hline TRADE & $\begin{array}{c}0.46^{* * *} \\
(0.05)\end{array}$ & $\begin{array}{c}0.66^{* * *} \\
(0.06)\end{array}$ & $\begin{array}{c}0.03 \\
(0.07)\end{array}$ & $\begin{array}{l}0.16^{* *} \\
(0.06)\end{array}$ & $\begin{array}{l}0.15^{* *} \\
(0.07)\end{array}$ & $\begin{array}{c}0.96^{* * *} \\
(0.32)\end{array}$ & $\begin{array}{l}0.78^{*} \\
(0.47)\end{array}$ & $\begin{array}{c}0.72 \\
(0.53)\end{array}$ \\
\hline MONFR & $\begin{array}{l}0.02^{* * *} \\
(0.006)\end{array}$ & $\begin{array}{l}0.002 * \\
(0.001)\end{array}$ & $\begin{array}{c}0.001 \\
(0.001)\end{array}$ & $\begin{array}{l}0.002 * \\
(0.001)\end{array}$ & $\begin{array}{l}0.02^{* * *} \\
(0.008)\end{array}$ & $\begin{array}{l}0.03^{* * *} \\
(0.008)\end{array}$ & $\begin{array}{l}0.03^{* * *} \\
(0.009)\end{array}$ & $\begin{array}{c}0.02^{* * *} \\
(0.01)\end{array}$ \\
\hline UNEM & $\begin{array}{c}-0.03^{* * *} \\
(0.006)\end{array}$ & $\begin{array}{c}-0.02^{* * *} \\
(0.002)\end{array}$ & $\begin{array}{c}-0.01^{* * *} \\
(0.001)\end{array}$ & $\begin{array}{l}-0.017 \\
* * * \\
(0.001)\end{array}$ & $\begin{array}{l}-0.01 * * \\
(0.006)\end{array}$ & $\begin{array}{r}-0.03^{* * *} \\
(0.1)\end{array}$ & $\begin{array}{r}-0.03^{* * *} \\
(0.01) ;(0.01)\end{array}$ & $\begin{array}{l}-0.02 \text { ** } \\
0.01)\end{array}$ \\
\hline CONINT & $\begin{array}{c}0.08^{* * *} \\
(0.02)\end{array}$ & $\begin{array}{l}0.01 * \\
(0.007)\end{array}$ & $\begin{array}{l}0.006 * * \\
(0.006)\end{array}$ & $\begin{array}{c}0.015^{* * *} \\
(0.005)\end{array}$ & $\begin{array}{c}0.072 * * \\
(0.03)\end{array}$ & $\begin{array}{c}0.12^{* * *} \\
(0.04)\end{array}$ & $\begin{array}{c}0.014^{* * *} \\
(0.04)\end{array}$ & $\begin{array}{c}0.05^{* * *} \\
(0.04)\end{array}$ \\
\hline BDEF & $\begin{array}{l}0.0003 \\
(0.008)\end{array}$ & $\begin{array}{l}-0.007 \\
(0.002)\end{array}$ & $\begin{array}{c}-0.007^{* *} \\
(0.002)\end{array}$ & $\begin{array}{c}-0.004^{* *} \\
(0.002)\end{array}$ & $\begin{array}{c}-0.02 * * \\
(0.01)\end{array}$ & $\begin{array}{c}-0.02 * * \\
(0.01)\end{array}$ & $\begin{array}{c}-0.03^{*} \\
(0.01)\end{array}$ & $\begin{array}{c}-0.03^{*} \\
(0.01)\end{array}$ \\
\hline PSP & $\begin{array}{l}0.02 * * * \\
(0.003)\end{array}$ & $\begin{array}{c}0.006^{* * *} \\
(0.001)\end{array}$ & $\begin{array}{l}0.0006 \\
(0.001)\end{array}$ & $\begin{array}{l}0.0007 \\
(0.001)\end{array}$ & $\begin{array}{c}-0.01^{* * *} \\
(0.004)\end{array}$ & $\begin{array}{l}-0.01 \\
(0.009)\end{array}$ & $\begin{array}{c}-0.01 * * \\
(0.009)\end{array}$ & $\begin{array}{c}-0.006 \\
(0.01)\end{array}$ \\
\hline GRS & $\begin{array}{c}0.005 \\
(0.004)\end{array}$ & $\begin{array}{c}0.008^{* * *} \\
(0.001)\end{array}$ & $\begin{array}{l}0.01 * * * \\
(0.001)\end{array}$ & $\begin{array}{c}0.009^{* * *} \\
(0.001)\end{array}$ & $\begin{array}{l}0.01 * \\
(0.005)\end{array}$ & $\begin{array}{c}0.01 \\
(0.009)\end{array}$ & $\begin{array}{c}0.01 \\
(0.009)\end{array}$ & $\begin{array}{c}0.03^{* * *} \\
(0.01)\end{array}$ \\
\hline CRHO & $\begin{array}{l}0.10^{* * *} \\
(0.012)\end{array}$ & $\begin{array}{c}0.007 \\
(0.006)\end{array}$ & $\begin{array}{c}0.016^{* * *} \\
(0.005)\end{array}$ & $\begin{array}{c}0.019^{* * *} \\
(0.004)\end{array}$ & $\begin{array}{l}0.04^{* *} \\
(0.01)\end{array}$ & $\begin{array}{l}0.06^{*} \\
(0.03)\end{array}$ & $\begin{array}{l}0.07^{* *} \\
(0.03)\end{array}$ & $\begin{array}{l}0.07^{* *} \\
(0.03)\end{array}$ \\
\hline Cons & $\begin{array}{c}2.94^{* * *} \\
(0.66)\end{array}$ & $\begin{array}{c}5.52 * * * \\
(0.32)\end{array}$ & $\begin{array}{c}9.38^{* * *} \\
(0.37)\end{array}$ & $\begin{array}{c}9.12^{* * *} \\
(0.33)\end{array}$ & $\begin{array}{c}0.59^{* * *} \\
(0.85)\end{array}$ & $\begin{array}{c}6.18^{* * *} \\
(1.66)\end{array}$ & $\begin{array}{l}4.2^{* * *} \\
(1.40)\end{array}$ & $\begin{array}{c}3.71 * * * \\
(1.76)\end{array}$ \\
\hline R squared & 0.72 & 0.66 & 0.81 & 0.81 & 0.23 & 0.20 & 0.31 & 0.36 \\
\hline F statistic & $33.65 * * *$ & $46.93^{* * *}$ & $52 * * *$ & $50.89^{* * *}$ & $3.97 * * *$ & \multicolumn{3}{|c|}{$5.06^{* * *} \cdot 4.24^{* * *} \cdot 4.30^{* * *} \cdot 0.30^{* * *}$} \\
\hline Obs. & 392 & 392 & 392 & 365 & 392 & 392 & 392 & 365 \\
\hline
\end{tabular}

The SEPA cards are an important factor of monetary integration which can influence economic growth because they foster cross-border trade relations and investments across countries. Additionally, SEPA payments can improve the conditions for customers, foster innovation and competition, which can also influence economic growth [35]. The money supply is important because it can help the economist to develop monetary policies and influence the financing of government budgets, and adjusting the money supply is considered a tool for managing the economic activity which can lead to output growth [36]. Trade is an indicator of the openness of an economy and it can positively influence economic growth because it can foster economic empowerment according to the investment possibilities in economic projects in the global arena and also can develop access to foreign resources, technology and markets [37]. Monetary freedom can have a positive impact on economic growth [38] because, according to Heritage Foundation, it is based on price control and price stability, key factors of EMU (price stability is one of the convergence criteria) which leads to economic growth.

The convergence of interest rates is an important factorfor monetary integration, according to the Maastricht criteria, which can have a positive influence on economic growth because limiting differences among interest rates allows us to move away from arbitration in the financial markets [27]. If the interest rates deflect significantly removed from the mean, the problem ofcurrency depreciation can stand out, which can also lead to an unbalanced balance of payments, the loss of foreign capital and currency reserves, which can have a negative influence on growth [39]. Gross savings wereintroduced in the model as a control variable which can influence the dependent variable. Cross-border holdings of 
short-term debt arealso important for economic growth because they represent a factor of cross-border activity, which can strengthen the possibility of countries to be more competitive internationally and to export more. Unemployment rates were used as a control variable, because, according to the literature, there exists an indirect relationship between unemployment and economic growth. Therefore, according to this model, we can accept the hypothesis that monetary integration fosters economic growth.

Through the differences between euro and non-euro countries (model 2- and model 3-Tables 4 and 5), we can see that, in the Eurozone, the variables which refer to the monetary integration (the convergence of exchange rates, the convergence of interest rates, SEPA cards, money supply, trade, monetary freedom, cross-border holdings) have a positive and more significant impact on economic growth than in the non-euro countries, both for GDP and total factor productivity. The convergence of inflation has a positive and significant impact only on GDP. The convergence criteria of exchange rates, interest rates and inflation established by the Maastricht Treaty evolved after the introduction of the euro, as a sign of "sustainable economic convergence", which is also reflected in the economic growth, especially in GDP growth [40].

Table 4. The impact of monetary integration on economic growth: Model 2-Eurozone.

\begin{tabular}{|c|c|c|c|c|c|c|c|c|}
\hline \multirow{5}{*}{$\begin{array}{c}\begin{array}{c}\text { Independent } \\
\text { Variables }\end{array} \\
\text { CONCPI }\end{array}$} & \multicolumn{4}{|c|}{ Dependent Variable-GDP } & \multicolumn{4}{|c|}{ Dependent Variable-TFP } \\
\hline & \multirow{2}{*}{$\begin{array}{c}\text { OLS with } \\
\text { Years Dummy }\end{array}$} & \multicolumn{3}{|c|}{ Fixed Effects } & \multirow{2}{*}{$\begin{array}{c}\text { OLS with } \\
\text { Years Dummy }\end{array}$} & \multicolumn{3}{|c|}{ Fixed Effects } \\
\hline & & \multicolumn{3}{|c|}{ Country FE Year FE Year FE (2) } & & \multicolumn{3}{|c|}{ Country FE Year FE Year FE (2) } \\
\hline & 0.014 & $0.0003 *$ & $0.02 * *$ & $0.015^{* *}$ & 0.03 & $0.12 * *$ & $0.14^{* *}$ & 0.04 \\
\hline & $(0.024)$ & $(0.009)$ & $(0.009)$ & $(0.007)$ & $(0.04)$ & $(0.05)$ & $(0.06)$ & $(0.07)$ \\
\hline \multirow{2}{*}{ CONEXR } & $3.04^{* * *}$ & $0.03^{* * *}$ & $1.17^{* * *}$ & $0.75^{* * *}$ & 0.02 & 0.001 & $0.28 *$ & $1.65^{* * *}$ \\
\hline & $(1.00)$ & $(0.008)$ & $(0.31)$ & $(0.26)$ & $(1.04)$ & $(0.04)$ & $(0.24)$ & $(0.50)$ \\
\hline \multirow{2}{*}{ SCT } & $0.007^{* *}$ & 0.001 & 0.002 & 0.02 & $0.03^{* *}$ & $0.06^{* *}$ & $0.06^{* *}$ & $0.06^{*}$ \\
\hline & $(0.01)$ & $(0.005)$ & $(0.004)$ & $(0.003)$ & $(0.01)$ & $(0.02)$ & $(0.02)$ & $(0.03)$ \\
\hline \multirow{2}{*}{ SDD } & $0.015^{* *}$ & $0.001 *$ & 0.003 & $0.02 * *$ & 0.01 & $0.05^{* *}$ & $0.05^{* *}$ & $0.05 *$ \\
\hline & $(0.009)$ & $(0.003)$ & $(0.003)$ & $(0.002)$ & $(0.01)$ & $(0.02)$ & $(0.02)$ & $(0.02)$ \\
\hline \multirow{2}{*}{ SC } & $0.05^{* * *}$ & $0.08^{* * *}$ & $0.044^{* * *}$ & $0.03^{* * *}$ & 0.01 & $0.08^{* *}$ & $0.04^{* *}$ & $0.12^{* * *}$ \\
\hline & $(0.01)$ & $(0.01)$ & $(0.011)$ & $(0.009)$ & $(0.01)$ & $(0.07)$ & $(0.07)$ & $(0.09)$ \\
\hline \multirow{2}{*}{ MS } & $0.10^{* * *}$ & 0.01 & $0.03^{* * *}$ & $0.02^{* *}$ & $0.09^{* * *}$ & $0.22^{* * *}$ & $0.24^{* * *}$ & $0.25^{* *}$ \\
\hline & $(0.02)$ & $(0.01)$ & $(0.01)$ & $(0.01)$ & $(0.03)$ & $(0.07)$ & $(0.07)$ & $(0.10)$ \\
\hline \multirow{2}{*}{ TRADE } & $0.40^{* * *}$ & $0.62^{* * *}$ & $0.10^{*}$ & $0.27^{* * *}$ & 0.07 & $0.83^{* *}$ & $0.47^{*}$ & 0.10 \\
\hline & $(0.04)$ & $(0.07)$ & $(0.08)$ & $(0.07)$ & $(0.06)$ & $(0.42)$ & $(0.59)$ & $(0.06)$ \\
\hline \multirow{2}{*}{ MONFR } & $0.011^{* *}$ & $0.007^{* * *}$ & $0.004^{* *}$ & $0.005^{* * *}$ & $0.014^{*}$ & 0.01 & 0.02 & 0.01 \\
\hline & $(0.006)$ & $(0.002)$ & $(0.001)$ & $(0.001)$ & $(0.008)$ & $(0.01)$ & $(0.01)$ & $(0.01)$ \\
\hline \multirow{2}{*}{ UNEM } & $-0.03^{* * *}$ & $-0.02^{* * *}$ & $\underset{* * *}{-0.019}$ & $-0.01^{* * *}$ & $-0.009^{* * *}$ & $-0.02^{* *}$ & $-0.1^{* *}$ & $-0.01^{* *}$ \\
\hline & $(0.005)$ & $(0.002)$ & $(0.001)$ & $(0.001)$ & $(0.007)$ & $(0.01)$ & $(0.01)$ & $(0.01)$ \\
\hline \multirow{2}{*}{ CONINT } & $0.002 *$ & $0.01^{* *}$ & 0.004 & $0.01^{* *}$ & $0.02^{* * *}$ & $0.09 * *$ & $0.08^{*}$ & $0.05^{* *}$ \\
\hline & $(0.01)$ & $(0.007)$ & $(0.003)$ & $(0.005)$ & $(0.02)$ & $(0.04)$ & $(0.04)$ & $(0.03)$ \\
\hline \multirow{2}{*}{ BDEF } & $0.006 *$ & $-0.01^{* * *}$ & $\underset{* * *}{-0.009}$ & $-0.005^{* *}$ & -0.01 & $-0.03^{* *}$ & $-0.03 *$ & -0.03 \\
\hline & $(0.007)$ & $(0.002)$ & $(0.002)$ & $(0.002)$ & $(0.01)$ & $(0.01)$ & $(0.01)$ & 0.02 \\
\hline \multirow{2}{*}{ PSP } & $0.01^{* * *}$ & 0.002 & $-0.002 *$ & -0.001 & $-0.009^{*}$ & -0.01 & -0.01 * & -0.01 \\
\hline & $(0.003)$ & $(0.001)$ & $(0.001)$ & $(0.001)$ & $(0.004)$ & $(0.01)$ & $(0.01)$ & $(0.01)$ \\
\hline \multirow{2}{*}{ GRS } & $0.010^{* * *}$ & $0.005^{* * *}$ & $0.009^{* * *}$ & $0.008^{* * *}$ & $0.009^{*}$ & $0.02 *$ & $0.02^{* *}$ & $0.04^{* * *}$ \\
\hline & $(0.003)$ & $(0.001)$ & $(0.001)$ & $(0.001)$ & $(0.005)$ & $(0.01)$ & $(0.01)$ & $(0.01)$ \\
\hline \multirow{2}{*}{ CRHO } & $0.16^{* * *}$ & 0.002 & 0.07 * & $0.01 *$ & 0.009 & $0.12^{* *}$ & $0.13^{* *}$ & $0.11^{* *}$ \\
\hline & $(0.01)$ & $(0.008)$ & $(0.007)$ & $(0.006)$ & $(0.01)$ & $(0.04)$ & $(0.05)$ & $(0.06)$ \\
\hline \multirow{2}{*}{ Cons } & $14.2^{* * *}$ & $6.21^{* * *}$ & $1.79^{* * *}$ & $4.11^{* * *}$ & $1.45^{* * *}$ & $3.06^{* * *}$ & $0.96^{* * *}$ & $10.66^{* *}$ \\
\hline & (1.36) & $(0.39)$ & $(0.61)$ & (1.67) & $(0.84)$ & (1.22) & (1.21) & (1.97) \\
\hline R squared & 0.81 & \multicolumn{3}{|c|}{$0.71 ; 0.83 ; 0.85 ; 0.85$} & 0.30 & 0.30 & 0.33 & 0.36 \\
\hline F statistic & $36.93^{* * *}$ & $39.01^{* * *}$ & $37.96^{* * *}$ & $41.76^{* * *}$ & $2.90^{* * *}$ & $3.93^{* * *}$ & $3.10^{* * *}$ & $2.52^{* * *}$ \\
\hline Obs. & 252 & 252 & 252 & 231 & 252 & 252 & 252 & 231 \\
\hline
\end{tabular}


Table 5. The impact of monetary integration on economic growth: Model 3-Non-euro.

\begin{tabular}{|c|c|c|c|c|c|c|c|c|}
\hline \multirow{4}{*}{$\begin{array}{c}\text { Independent } \\
\text { Variables } \\
\\
\text { CONCPI }\end{array}$} & \multicolumn{4}{|c|}{ Dependent Variable-GDP } & \multicolumn{4}{|c|}{ Dependent Variable-TFP } \\
\hline & \multirow{3}{*}{$\begin{array}{c}\begin{array}{c}\text { OLS with } \\
\text { Years Dummy }\end{array} \\
-0.0007 \\
(0.036)\end{array}$} & \multicolumn{3}{|c|}{ Fixed Effects } & \multirow{3}{*}{$\begin{array}{c}\begin{array}{c}\text { OLS with } \\
\text { Years Dummy }\end{array} \\
0.01 \\
(0.06)\end{array}$} & \multicolumn{3}{|c|}{ Fixed Effects } \\
\hline & & \multicolumn{3}{|c|}{ Country FE, Year FE, Year FE (2) } & & \multicolumn{3}{|c|}{ Country FE, Year FE, Year FE (2) } \\
\hline & & $\begin{array}{c}-0.05^{* * *} \\
(0.01)\end{array}$ & $\begin{array}{c}0.01 \\
(0.014)\end{array}$ & $\begin{array}{c}-0.014^{*} \\
(0.007)\end{array}$ & & $\begin{array}{l}-0.09 \\
(0.06)\end{array}$ & $\begin{array}{c}-0.13 \text { ** } \\
(0.06)\end{array}$ & $\begin{array}{c}-0.08 \\
(0.008)\end{array}$ \\
\hline CONEXR & -0.004 & $-0.004^{* *}$ & $-\underset{* * *}{-0.008}$ & $-0.78^{* * *}$ & 0.0006 & 0.09 & -0.32 & 0.008 \\
\hline & $(0.001)$ & $(0.002)$ & $(0.001)$ & $(0.26)$ & $(0.002)$ & $(0.009)$ & $(0.04)$ & $(0.001)$ \\
\hline SCT & $\begin{array}{c}0.02 \\
(0.01)\end{array}$ & $\begin{array}{l}0.02 * * \\
(0.01)\end{array}$ & $\begin{array}{l}0.01 * \\
(0.009)\end{array}$ & $\begin{array}{c}-0.002 * \\
(0.003)\end{array}$ & $\begin{array}{c}0.04 \\
(0.02)\end{array}$ & $\begin{array}{l}-0.01 \\
(0.006)\end{array}$ & $\begin{array}{c}-0.06^{* *} \\
(0.02)\end{array}$ & $\begin{array}{c}0.08 \\
(0.07)\end{array}$ \\
\hline SDD & $\begin{array}{c}0.06^{* * *} \\
(0.01)\end{array}$ & $\begin{array}{c}0.008 \\
(0.006)\end{array}$ & $\begin{array}{c}0.006 \\
(0.005)\end{array}$ & $\begin{array}{l}0.0005 \\
(0.002)\end{array}$ & $\begin{array}{c}-0.06^{* * *} \\
(0.029)\end{array}$ & $\begin{array}{c}0.07 \\
(0.003)\end{array}$ & $\begin{array}{l}0.05^{* *} \\
(0.02)\end{array}$ & $\begin{array}{c}-0.004 \\
(0.02)\end{array}$ \\
\hline $\mathrm{SC}$ & $\begin{array}{c}0.04 \\
(0.01)\end{array}$ & $\begin{array}{c}0.03^{* * *} \\
(0.01)\end{array}$ & $\begin{array}{c}0.01 \\
(0.008)\end{array}$ & $\begin{array}{c}0.03 * \\
(0.009)\end{array}$ & $\begin{array}{c}0.01 \\
(0.002)\end{array}$ & $\begin{array}{l}-0.02 \\
(0.004)\end{array}$ & $\begin{array}{c}0.04 \\
(0.007)\end{array}$ & $\begin{array}{c}0.04 \\
(0.006)\end{array}$ \\
\hline MS & $\begin{array}{c}0.55^{* * *} \\
(0.07)\end{array}$ & $\begin{array}{c}0.13^{* * *} \\
(0.04)\end{array}$ & $\begin{array}{c}0.10^{* * *} \\
(0.03)\end{array}$ & $\begin{array}{c}-0.02^{* *} \\
(0.01)\end{array}$ & $\begin{array}{c}0.37^{* * *} \\
(0.14)\end{array}$ & $\begin{array}{c}1.34^{* * *} \\
(0.19)\end{array}$ & $\begin{array}{c}-0.24 * * * \\
(0.07)\end{array}$ & $\begin{array}{l}-0.62 \\
(0.08)\end{array}$ \\
\hline TRADE & $\begin{array}{c}-0.47^{* * *} \\
(0.14)\end{array}$ & $\begin{array}{c}0.41^{* * *} \\
(0.10)\end{array}$ & $\begin{array}{c}-0.41^{*} \\
(0.11)\end{array}$ & $\begin{array}{l}-0.26 \\
(0.07)\end{array}$ & $\begin{array}{c}0.15 \\
(0.02)\end{array}$ & $\begin{array}{l}-0.63 \\
(0.51)\end{array}$ & $\begin{array}{c}0.51 \\
(0.05)\end{array}$ & $\begin{array}{c}2.37^{* * * *} \\
(0.99)\end{array}$ \\
\hline MONFR & $\begin{array}{c}-0.1 \\
(0.008)\end{array}$ & $\begin{array}{l}-0.004 \\
(0.002)\end{array}$ & $\begin{array}{c}0.002 \\
(0.002)\end{array}$ & $\begin{array}{c}-0.005 * \\
(0.001)\end{array}$ & $\begin{array}{l}0.04^{* *} \\
(0.011)\end{array}$ & $\begin{array}{c}0.020^{* *} \\
(0.01)\end{array}$ & $\begin{array}{c}0.02 \\
(0.01)\end{array}$ & $\begin{array}{c}0.05^{*} \\
(0.012)\end{array}$ \\
\hline UNEM & $-0.05^{* * *}$ & $-0.02 * * *$ & $-0.02 * * *$ & $-\underset{* * *}{0.011}$ & $-0.02 * *$ & $-0.04^{* * *}$ & $-0.01 * * *$ & $-0.03 *$ \\
\hline & $(0.009)$ & $(0.004)$ & $(0.003)$ & $(0.001)$ & $(0.01)$ & $(0.02)$ & $(0.01)$ & $(0.03)$ \\
\hline CONINT & $\begin{array}{c}-0.03 \text { ** } \\
(0.004)\end{array}$ & $\begin{array}{c}-0.021 \\
(0.01)\end{array}$ & $\begin{array}{c}-0.02 * * * \\
(0.013)\end{array}$ & $\begin{array}{c}-0.01 * * \\
(0.005)\end{array}$ & $\begin{array}{c}-0.29 * * \\
(0.08)\end{array}$ & $\begin{array}{c}-0.18^{* *} \\
(0.09)\end{array}$ & $\begin{array}{l}-0.09 \\
(0.04)\end{array}$ & $\begin{array}{c}0.19 \\
(0.13)\end{array}$ \\
\hline BDEF & $\begin{array}{c}0.032^{* * *} \\
(0.010)\end{array}$ & $\begin{array}{l}-0.03 \\
(0.005)\end{array}$ & $\begin{array}{c}-0.0005 \\
(0.004)\end{array}$ & $\begin{array}{c}-0.005^{* *} \\
(0.002)\end{array}$ & $\begin{array}{l}-0.02 \\
(0.002)\end{array}$ & $\begin{array}{c}0.03 \\
(0.02)\end{array}$ & $\begin{array}{l}-0.03 * \\
(0.01)\end{array}$ & $\begin{array}{l}-0.02 \\
(0.003)\end{array}$ \\
\hline PSP & $\begin{array}{l}0.04^{* * *} \\
(0.005)\end{array}$ & $\begin{array}{c}0.009^{* * *} \\
(0.003)\end{array}$ & $\begin{array}{c}0.004 \\
(0.002)\end{array}$ & $\begin{array}{c}0.001 \\
(0.001)\end{array}$ & $\begin{array}{l}-0.011 \\
(0.010)\end{array}$ & $\begin{array}{l}-0.09 \\
(0.01)\end{array}$ & $\begin{array}{l}-0.01 \\
(0.010)\end{array}$ & $\begin{array}{l}-0.009 \\
(0.002)\end{array}$ \\
\hline GRS & $\begin{array}{l}0.05^{* * *} \\
(0.007)\end{array}$ & $\begin{array}{l}0.01^{* *} \\
(0.004)\end{array}$ & $\begin{array}{c}0.013^{* * *} \\
(0.003)\end{array}$ & $\begin{array}{c}0.008 \\
(0.001)\end{array}$ & $\begin{array}{l}-0.02 * \\
(0.017)\end{array}$ & $\begin{array}{l}-0.03 \\
(0.02)\end{array}$ & $\begin{array}{l}0.02 * \\
(0.014)\end{array}$ & $\begin{array}{c}-0.027 \\
(0.02)\end{array}$ \\
\hline CRHO & $\begin{array}{l}0.05^{* *} \\
(0.01)\end{array}$ & $\begin{array}{c}-0.018^{* *} \\
(0.008)\end{array}$ & $\begin{array}{c}-0.02 * * * \\
(0.006)\end{array}$ & $\begin{array}{c}-0.016^{* *} \\
(0.006)\end{array}$ & $\begin{array}{l}-0.07^{*} \\
(0.03)\end{array}$ & $\begin{array}{c}0.01 \\
(0.003)\end{array}$ & $\begin{array}{c}-0.13^{* * *} \\
(0.05)\end{array}$ & $\begin{array}{l}-0.01 \\
(0.005)\end{array}$ \\
\hline Cons & $\begin{array}{c}5.11^{* * *} \\
(0.92)\end{array}$ & $\begin{array}{c}5.84^{* * *} \\
(0.59)\end{array}$ & $\begin{array}{c}10.01^{* * *} \\
(0.58)\end{array}$ & $\begin{array}{c}3.94 * * * \\
(1.70)\end{array}$ & $\begin{array}{c}3.29 * * * \\
(1.68)\end{array}$ & $\begin{array}{c}3.26^{* * *} \\
(0.88)\end{array}$ & $\begin{array}{c}1.09^{* * *} \\
(1.13)\end{array}$ & $\begin{array}{c}4.83^{* * *} \\
(1.45)\end{array}$ \\
\hline R squared & 0.94 & 0.80 & 0.91 & 0.85 & 0.57 & 0.54 & 0.63 & 0.54 \\
\hline F statistic & $64.92 * * *$ & $30.88^{* * *}$ & $37.21^{* * *}$ & $41.86^{* * *}$ & $5^{* * *}$ & $8.82 * * *$ & $27.45^{* * *}$ & $18.75^{* * *}$ \\
\hline Obs. & 140 & 140 & 140 & 128 & 140 & 140 & 140 & 128 \\
\hline
\end{tabular}

The convergence of nominal variables accompanies the real convergence of economies in macroeconomic terms. The creation of a propitious environment for the long-term economic growth should be realized by the purpose of the Maastricht criteria to guarantee macroeconomic or monetary stability in the euro area [41]. SEPA payments are more developed in the euro countries, and they are practiced in the non-euro ones, because the cross-border relations between countries are easier in the countries with single currency systems, even if the non-euro countries may also extend the application of these regulations to their national currency, like Sweden and Romania.

Trade is more developed in the euro countries because it is a criterion of optimal currency area which is related to monetary integration (the OCA (optimal currency area) criteria are related to decisions on economic integration, so that the aspiration of a monetary union becomes a part of a function of the underlying political choices, and also the creation of a common monetary policy is rendered by the fact that its financial systems which can be used as an insurance mechanism carry out the similar activity), the single currency facilitates cross-border trade across countries and trade integration, and also, according to the statistical information, trade registered higher values in the Eurozone than in non-euro countries. Money supply has a greater influence on growth in the euro countries because a single currency supports the single market in which the monetary policy fosters the economy by a central bank monitoring and controlling the necessary money supply of that economy. Monetary freedom has a greater influence in the euro countries because according to the convergence 
criteria, their main objective consists in price stability, and, according to a report by the European Central Bank [16-18], cross-border holdings of short-term debt are an important indicator of market integration in the euro area, which registered an increasing trend between 2000 and 2007, and is considered an important source of sustainable funding for the banks from euro countries. Therefore, according to these models, we can accept the hypothesis that monetary integration has a greater impact on economic growth in the Eurozone.

The Monetary Union has successfully established a credible monetary policy framework with low inflation and a stable exchange rate, as well as a synchronization of the business cycle and the financial cycle, and, moreover, the achievement of sustainable economic convergence in the euro area is an essential obligation of every EU Member State in the social contract upon which the Monetary Economic Union was founded.

However, in order to improve economic performance and in order to cushion divergent shocks, stronger policies are needed, namely the recalibration of Eurozone fiscal rules to allow for higher countercyclical policies, together with a common fiscal capacity (because many national governments have failed to exercise sufficient fiscal discipline and undertake sufficient structural reforms), more intensive use of macro-prudential regulations to stimulate the synchronization and alignment of financial cycles, and structural reforms that stimulate productivity growth and enable states to cope more easily with heterogeneous economic shocks, and last but not least, in order to be able to share the benefits of Monetary Union with all European citizens, greater convergence of income levels would be needed.

Real convergence in the Eurozone is also strongly supported by the improvement of institutional quality, which gives it its sustainability character.

After this section, with the results obtained from the econometric analysis, the finalsection summarizes the main conclusions, proposals, policy implications and future directions of the research on this topic.

\section{Conclusions}

The relationship between monetary integration and economic growth is a controversial issue thatdid not benefit from a great deal of attention in the revised studies. The purpose of this study was to investigate the relationship between monetary integration and economic growth in the countries of the European Union and to find the main factors inthe development of the money market that influence economic growth. We used data from $28 \mathrm{EU}$ countries from the period 2004-2018.

We used the fixed-effects model for country and time effects to see what the differences between euro and non-euro countries are. The results showthat the main factors through monetary integration foster significant and positive economic growth, which confirms the hypothesis that monetary integration fosters economic growth, such as throughSEPA cards, trade, monetary freedom, convergence of interest rates, convergence of exchange rates and cross-border holdings of short-term debt, with significant differences between Eurozone and non-euro countries, which confirms the hypothesis that the introduction of the euro had a significant impact on economic and financial integration.

The nominal convergence of the Maastricht criteria played an essential role in order to ensure macroeconomic stability and sustainable economic growth. Due to the fact that they cannot guarantee long-term high standards of living and the convergence of the economic structures, they create the premises for the economy to achieve real convergence at the macroeconomic level. The most important reason for the need fora sustainable economic convergence consists in contrast to the tendency of divergence of the Eurozone from other advanced economies.

Regarding the use of the SEPA cards, the banks have shown interest through the stimulation of the customers to modify their payment behaviour and to use these more efficient and less costly payment means. An important stage towards European integration consists in the functioning of the SEPA project. 
Additionally, the cross-border activity, represented in our case by trade and cross-border holdings of short-term debt securities, is linked with the development and growth of the economy, because the main stages of cross-border economic integration refer to a free trade area, freedom of movements of goods and services across countries, without limitations of the movement of production factors, the harmonization of the economic policies, the reunion of supranational authorities, monetary policies and foreign exchange.

Policymakers in this area should consider easing the efforts made at the national level through rules and careful follow-up procedures, that contribute to eliminate the negative spillovers across countries, developing a long-term perspective on nominal and real convergence which leads to the prioritization of policies that support the main role of the productivity in stimulating sustainable economic convergence and encouraging the cross-border activities across countries, and the central banks must enact the continuous monitoring of the conditions and trends of bank funding markets, to have a closer coordination on monetary policies across all the EU countries, to aid consumer protection and increase innovation and competition through specifying some suitable conditions for people who want to join the retail payment market (through encouragement of SEPA payments and technological progress, also the development of new products, such as e-invoicing), all with the overall goal of stability and growth.

Although the indicators we use to measure convergence are based on the criteria of nominal convergence, nominal and real convergence are closely linked, as nominal convergence facilitates real convergence by ensuring stable macroeconomic conditions. In addition to convergence indicators, SEPA instruments also play a key role in facilitating monetary integration, as the operation of this system can bring many benefits to economic growth and stability, such as increasing competition in the banking industry by removing barriers previously protected by national markets, guaranteeing cost savings in payment processing and thus the emergence of new business opportunities, stimulating innovation and improving trading conditions for bank customers. Countries can only enjoy these benefits if all euro payments (for Eurozone countries) are treated as domestic payments and when the distinction between national and cross-border payments disappears. The institutions that could benefit most from the SEPA project are those that carry out new technological developments, create new companies or businesses and provide innovative services. Last but not least, cross-border activity (expressed in this chapter of the thesis through trade and cross-border short-term debt holdings) also occupies an important place in highlighting the relationship between money market integration and economic growth, statistics suggesting an increase after the introduction of the euro, and our results confirm the significant impact of this on economic growth.

In other research, it would be interesting to use another indicator for measuring the law of the single price, namely the parity of the interest rate, which is a limit for the research carried out in this doctoral thesis, due to the unavailability of data. Another direction could be considered in the extension of the sample to a more recent period (2018), to observe the evolution of the indicators on integration at the current stage, given that the research stopped in 2016 for the capital market and 2017 for the other two markets, due to the lack of data available, which can be considered another limitation of this doctoral research. Moreover, we consider that it would be interesting to study the differentiated impact of financial integration on economic growth on a country-by-country basis, in order to observe which country has contributed more to the evolution of this process.

Author Contributions: Conceptualization, I.B., O.-R.O. and O.S.; methodology, I.B., O.-R.O. and O.S.; software, I.B., O.-R.O. and O.S.; validation, I.B., O.-R.O. and O.S.; formal analysis, I.B., O.-R.O. and O.S.; investigation, I.B., O.-R.O. and O.S.; resources, I.B., O.-R.O. and O.S.; data curation, I.B., O.-R.O. and O.S.; writing-original draft preparation, I.B., O.-R.O. and O.S.; writing-review and editing, I.B., O.-R.O. and O.S.; visualization, I.B., O.-R.O. and O.S.; supervision, I.B., O.-R.O. and O.S.; project administration, I.B., O.-R.O. and O.S.; funding acquisition, I.B., O.-R.O. and O.S. All authors have read and agreed to the published version of the manuscript.

Funding: This research received no external funding.

Conflicts of Interest: The authors declare no conflict of interest. 


\section{References}

1. Cham, T. Does monetary integration lead to an increase in FDI flows? An empirical investigation from the West African Monetary Zone (WAMZ). BorsaIstanb. Rev. 2016, 16, 9-20. [CrossRef]

2. Todorov, I. The Monetary Integration of the New Member States before the Euro Area Debt Crisis. Manag. Glob. Transit. 2013, 11, 375-390.

3. Smitha, T.H. Impact of Monetary Policy on Indian Economy in the Post-Reform Period. Ph.D. Thesis, Department of Applied Economics, Cochin University of Science and Technology, Kochi, India, 2010. Available online: https://dyuthi.cusat.ac.in/jspui/bitstream/purl/2159/3/Dyuthi-T0517.pdf (accessed on 25 July 2020).

4. Auray, S.; Eyquem, A.; Poutineau, J.-C. The welfare gains of trade integration in the european monetary union. Macroecon. Dyn. 2010, 14, 645-676. [CrossRef]

5. Chen, M.; Wu, J.; Jeon, B.N.; Wang, R. Monetary policy and bank risk-taking: Evidence from emerging economies. Emerg. Mark. Rev. 2017, 31, 116-140. [CrossRef]

6. Artis, M.; Zhang, W. International Business Cycles and the ERM: Is There a European Business Cycle? Int. J. Financ. Econ. 1997, 2, 1-16. [CrossRef]

7. Artis, M. Should the UK Join Emu? Natl. Inst. Econ. Rev. 2000, 171, 70-81. [CrossRef]

8. Micossi, S. The Monetary Policy of the European Central Bank (2002-2015); Centre for European Policy Studies: Manchester, UK, 2015.

9. Uxo, J. Is the end of fiscal austerity feasible in Spain? An alternative plan to the current Stability Programme (2015-2018). Camb. J. Econ. 2017, 41, 999-1020. [CrossRef]

10. Altavilla, C.; Pagano, M.; Simonelli, S. Bank Exposures and Sovereign Stress Transmission. Rev. Financ. 2017, 21, 2103-2139. [CrossRef]

11. Wyplosz, C. The Eurozone Crisis: A Near-Perfect Case of Mismanagement. Available online: https: //link.springer.com/chapter/10.1007/978-3-319-63706-8_2 (accessed on 27 August 2020).

12. De Grauwe, P. Economics of the Monetary Union, 13th ed.; Oxford University Press: New York, NY, USA, 2020.

13. Tomann, H. Monetary Integration in Europe; Springer Science and Business Media: Berlin, Germany, 2017.

14. Kalemli-Ozcan, S.; Manganelli, S.; Papaioannou, E.; Peydro, J.S. Financial Integration and Risk Sharing: The Role of the Monetary Union. Available online: http://citeseerx.ist.psu.edu/viewdoc/download?doi=10.1. 1.492.3198\&rep=rep1\&type=pdf (accessed on 23 July 2020).

15. Kalemli-Ozcan, S.; Papaioannou, E.; Peydró, J.-L. What Lies Beneath the Euro's Effect on Financial Integration: Currency Risk, Legal Harmonization, or Trade? J. Int. Econ. 2010, 81, 75-88. [CrossRef]

16. European Central Bank. The Single Euro Payments Area (SEPA)—An Integrated Retail Payment Market. Available online: https://www.ecb.europa.eu/pub/pdf/other/sepa_brochure_2009en.pdf (accessed on 21 July 2020).

17. European Central Bank. Single Euro Payments Area-Seventh Progress Report beyond Theory and Practice. Available online: https://www.ecb.europa.eu/pub/pdf/other/singleeuropaymentsarea201010en. pdf19 (accessed on 22 July 2020).

18. European Central Bank. Euro Area Markets for Banks' Long-Term Debt Financing Instruments: Recent Developments, State of Integration and Implications for Monetary Policy Transmission. Available online: https://www.ecb.europa.eu/pub/pdf/other/art2_mb201111en_pp73-90en.pdf (accessed on 22 July 2020).

19. Todorović, V.; Sedlarevic, L.; Tomic, N.; Violeta, T.; Lazar, S.; Nenad, T. Impact of the single euro payment area on performance of banking sector. Industrija 2017, 45, 23-44. [CrossRef]

20. Mare, C.; Litan, C. Perspectives on Euro introduction in the Romanian economy. Balt. J. Econ. 2012, 12, 23-40. [CrossRef]

21. Barrel, R.; Gottschalk, S.; Holland, D.; Khoman, E.; Liadze, I.; Pomerantz, O. The Impact of EMU on Growth and Unemployment. Eur. Com. Econ. Pap. 2008, 318, 35.

22. Mongelli, F.P. European Economic and Monetary Integration, and the Optimum Currency Area Theory. Eur. Com. Econ. Pap. 2008, 302, 44.

23. Bagnai, A.; Ospina, C.A.M. Monetary integration vs. real disintegration: Single currency and productivity divergence in the euro area. J. Econ. Policy Reform 2017, 21, 353-367. [CrossRef]

24. Nchake, M.A.; Edwards, L.; Rankin, N. Closer monetary union and product market integration in emerging economies: Evidence from the Common Monetary Area in Southern Africa. Int. Rev. Econ. Financ. 2018, 54, 154-164. [CrossRef] 
25. Quah, C.-H.; Crowley, P.M. Monetary Integration in East Asia: A Hierarchical Clustering Approach. Int. Financ. 2010, 13, 283-309. [CrossRef]

26. Walti, S. Stock Market Synchronization and Monetary Integration. A Publication of the National Centre of Competence in Research (NCCR) Supported by the Swiss National Science Foundation. NCCR. 2006. Available online: https://www.tcd.ie/Economics/staff/waltis/papers/eurofin.pdf (accessed on 23 July 2020).

27. Almunia, J. Monetary and Economic Integration-The EU Experience. European Commissioner for Economic and Monetary Affairs. 2006. Speech 06(529). Available online: https://ec.europa.eu/commission/presscorner/ detail/en/SPEECH_06_529 (accessed on 20 July 2020).

28. Kenen, P.B.; Meade, E.E. Monetary Integration in East Asia. Available online: https://www.frbsf.org/ economic-research/files/Kenen.pdf (accessed on 23 July 2020).

29. Saqib, N.; Aggarwal, P. Impact of Fiscal and Monetary Policyon Economic Growth in an Emerging Economy. Int. J. Appl. Bus. Econ. Res. 2017, 15, 457-462.

30. Candelon, B.; Muysken, J.; Vermeulen, R. Fiscal policy and monetary integration in Europe: An update. Oxf. Econ. Pap. 2009, 62, 323-349. [CrossRef]

31. Ramos, S.C. A Structural Analysis of the European Monetary Union and its Effect on Greece in Light of the European Financial Crisis. Master's Thesis, Claremont McKenna College, Claremont, CA, USA, 2011. Available online: https://scholarship.claremont.edu/cmc_theses/239 (accessed on 23 July 2020).

32. Barro, R.J. Economic Growth; MIT Press Cambridge: Cambridge, MA, USA, 2004.

33. Campos, N.F.; Macchiarelli, C. Symmetry and Convergence in Monetary Unions. Available online: https:// www.lse.ac.uk/european-institute/Assets/Documents/LEQS-Discussion-Papers/LEQSPaper131.pdf (accessed on 27 August 2020).

34. Ioannatos, P.E. Has the Euro Promoted Eurozone's Growth? J. Econ. Integr. 2018, 33, 1388-1411. [CrossRef]

35. Schmiedel, H. The Economic Impact of the Single Euro. ECB Occasional 2007. Paper Series No. 71. Available online: https://www.ecb.europa.eu//pub/pdf/scpops/ecbocp71.pdf (accessed on 22 July 2020).

36. Dingela, S.; Khobai, H. Dynamic Impact of Money Supply on Economic Growth in South Africa. In An ARDL Approach; MPRA Paper: Munchen, Germany, 2017.

37. Shafiei, E. International Trade and Its Impact on Economic Growth. Available online: http://www.ijirset.com/ upload/2014/march/52_Effect.pdf (accessed on 23 July 2020).

38. Ivanović, V.; Stanišić, N. Monetary freedom and economic growth in New European Union Member States. Econ. Res. Ekon. Istraživanja 2017, 30, 453-463. [CrossRef]

39. Bukowski, S.I. The Maastricht Convergence Criteria and Economic Growth in the EMU. Available online: http://www.ec.unipg.it/DEFS/uploads/quad24.pdf (accessed on 25 July 2020).

40. Del Hoyo, J.L.D.; Dorrucci, E.; Heinz, F.F.; Muzikarova, S. Real convergence in the euro area: A long-term perspective. Available online: https://www.ecb.europa.eu/pub/pdf/scpops/ecb.op203.en.pdf (accessed on 22 July 2020).

41. Drastichová, M. The relations of real and nominal convergence in the EU with impacts on the euro area participation. Ekon. Rev. Cent. Eur. Rev. Econ. Issues 2012, 15, 107-122. [CrossRef]

(C) 2020 by the authors. Licensee MDPI, Basel, Switzerland. This article is an open access article distributed under the terms and conditions of the Creative Commons Attribution (CC BY) license (http://creativecommons.org/licenses/by/4.0/). 